\title{
COL1A1 Gene
}

National Cancer Institute

\section{Source}

National Cancer Institute. COL1A1 Gene. NCI Thesaurus. Code C29949.

This gene plays an important structural role in cartilage and mutations in the gene are associated with osteogenesis imperfecta. 